\title{
Economic linkage impacts of Hawaii's longline fishing regulations
}

\author{
Junning Cai ${ }^{\mathrm{a}, \mathrm{b}}$, PingSun Leung ${ }^{\mathrm{a}, *}$, Minling Pan ${ }^{\mathrm{c}}$, Sam Pooley ${ }^{\mathrm{c}}$ \\ ${ }^{a}$ College of Tropical Agriculture and Human Resources, University of Hawaii at Manoa, \\ 3050 Maile Way, Gilmore 111, Honolulu, HI 96822, USA \\ ${ }^{\mathrm{b}}$ Department of Economics, University of Hawaii at Manoa, 3050 Maile Way, Gilmore 111, Honolulu, HI 96822, USA \\ ${ }^{\mathrm{c}}$ Pacific Islands Fisheries Science Center, National Marine Fisheries Services, \\ 2570 Dole Street, Honolulu, HI 96822, USA
}

Received 9 August 2004; received in revised form 29 January 2005; accepted 2 February 2005

\begin{abstract}
Fisheries regulations driven by environmental concerns would not only directly affect fisheries sectors but also tend to indirectly influence other sectors through intersectoral input-output linkages. This paper examines both backward and forward linkages of Hawaii's fisheries sectors to the rest of the economy, and based on this evaluates the potential economic impacts of longline fishing regulations in Hawaii. We find that Hawaii's fisheries sectors have strong linkages to the rest of the economy; regulations on them will thus have profound economic impacts.
\end{abstract}

(C) 2005 Elsevier B.V. All rights reserved.

Keywords: Hawaii longline fisheries; Economic impacts; Input-output modeling; Backward linkage; Forward linkage

\section{Introduction}

Growing environmental concerns make it increasingly difficult for fisheries to free-ride the environment. Since environment is a public property, fisheries regulations are usually needed to limit negative environmental impacts of fishing activities. As opposed to regulations for reducing over-fishing that tend to facilitate sustainable fisheries development, fisheries regulations driven by environmental concerns tend to constrain fisheries development by restraining

\footnotetext{
* Corresponding author. Tel.: +1 8089568562 ; fax: +1 8089569269 .

E-mail address: psleung@hawaii.edu (P. Leung).
}

fishing activities or making them more costly. Therefore, environmentally-driven fishery regulations should not only consider the social benefits of environmental protection but also need to take into account potential economic costs sacrificed for such protection.

Measuring economic impacts of fisheries regulations is not an easy task because while such regulations would directly affect fisheries sectors being regulated, they also tend to indirectly influence other sectors through intersectoral input-output linkages.

In this paper, we use Hawaii's longline fishing regulations as a case study to demonstrate the use of input-output modeling to estimate the economic impacts of fisheries regulations. 
Table 1

A profile of Hawaii's fishing industry (1997)

\begin{tabular}{|c|c|c|c|c|c|c|}
\hline Sectors & $\begin{array}{l}\text { Output } \\
\text { (US\$ million) }\end{array}$ & $\begin{array}{l}\text { Value-added } \\
\text { (US\$ million) }\end{array}$ & $\begin{array}{l}\text { Wage income } \\
\text { (US\$ million) }\end{array}$ & $\begin{array}{l}\text { Proprietor's income } \\
\text { (US\$ million) }\end{array}$ & Wage jobs & $\begin{array}{l}\text { Proprietor's } \\
\text { jobs }\end{array}$ \\
\hline Tuna longline & 27.37 & 16.46 & 7.30 & 2.49 & 215 & 191 \\
\hline Swordfish longline & 22.67 & 11.24 & 4.15 & 1.45 & 116 & 102 \\
\hline Small commercial boats & 11.70 & 6.55 & 0.29 & 5.40 & 10 & 507 \\
\hline Charter boats & 14.17 & 8.39 & 4.67 & 1.42 & 175 & 67 \\
\hline Expense boats & 3.94 & -0.32 & 0.00 & -0.78 & 0 & 1008 \\
\hline Recreation boats & 10.30 & 0.00 & 0.00 & 0.00 & 0 & 0 \\
\hline Total fishing industry & 90 & 42 & 16 & 10 & 516 & 1,875 \\
\hline Total Hawaii economy & 58,660 & 38,537 & 21,626 & 2,088 & 615,545 & 126,686 \\
\hline
\end{tabular}

Source: Hawaii 1997 input-output table (SMS, 2004).

In the next section, we first provide a brief profile of Hawaii's fisheries sectors and examine their linkages with other sectors in Hawaii. Then in Section 3, we estimate the potential economic impacts of Hawaii's longline fishing regulations intended to protect endangered species. Finally, Section 4 presents the conclusions.

\section{Linkages of Hawaii's fisheries sectors}

Hawaii's fishing industry is composed of six sectors: tuna longline, swordfish longline, small commercial boats, charter boats, expense boats, and recreation boats (Table 1), among which tuna and swordfish longline, small commercial boats, and expense boats belong to commercial or semi-commercial fishing ${ }^{1}$; whereas charter boats and recreation boats are for recreational purposes. ${ }^{2}$

Since sectors in an economy are interconnected through input-purchases or output-sales, fisheries

\footnotetext{
${ }^{1}$ Longline fisheries use $>30$ miles of surface-suspended mainline to catch pelagic species (primarily tunas and swordfish) and represents around $80 \%$ of Hawaii's commercial fisheries in terms of output. Longline fishermen set their mainline differently based on species targeted: gear is set shallow to target swordfish and deeper for tuna (Pradhan et al., 2003). Accordingly, longline fisheries are disaggregated into tuna longline and swordfish longline as two subsectors in the 1997 Hawaii fishery input-output model (SMS, 2004). As opposed to large longline vessels (greater than $35 \mathrm{ft}$ in length) using mainline as the fishing gear, small commercial vessels (16-33 ft in length) usually use handlining or trolling gears to fish mainly for tunas (Sharma et al., 2003), which represented around $20 \%$ of Hawaii's commercial fisheries in 1997. The expense boats sector comprises local residents who use private boats for semi-commercial fishing.

${ }^{2}$ Charter boats are used mainly by tourists for recreational fishing activities, while recreation boats are private boats used by local residents for recreational fishing.
}

regulations would not only directly affect fisheries sectors being regulated but also tend to indirectly influence other sectors in the economy through fisheries sectors' intersectoral "linkages". Accordingly, the impacts of fisheries regulations depend not only on the size of fisheries sectors but also on the strength of their linkages to non-fisheries sectors.

In the following, we examine the linkages of Hawaii's fisheries sectors to the rest of the economy. The examination provides general information about how fisheries production is linked to the production of other sectors and the magnitude of such linkages.

\subsection{Intersectoral input-output linkages: concept and measure}

A sector's relationship with its upstream suppliers through direct and indirect input-purchases is often called its "backward" linkage, while its relationship with downstream demanders through direct and indirect output-sales is called "forward" linkage (Chenery and Watanabe, 1958; Hirschman, 1958). For example, longline fisheries would need services to keep their fishing fleets in good condition, while firms that provide these services would need to purchase materials from their suppliers in order to conduct these services. In turn, these suppliers would need to purchase inputs from their own suppliers, and so on. The aggregation of all such direct and indirect input-purchasing relations constitutes longline fisheries' backward linkage. Similarly, but going forward, longline fisheries would supply fish products to food service industry, which would provide food services to hotel, entertainment places, or other businesses. 
The aggregation of all such direct and indirect outputselling relations constitutes longline fisheries' forward linkage.

While the concept of linkage is straightforward, its measure is nevertheless controversial (Cai and Leung, 2004). Here, we will follow the suggestion of Cai and Leung (2004) to use Leontief supply-driven multiplier as a backward-linkage measure and Ghosh supplydriven multiplier as the corresponding forward-linkage measure. ${ }^{3}$

These two standard linkage measures provide general and complementary information about intersectoral relationship. Sectors with large Leontief supply-driven multipliers have strong backward linkages, which implies that shocks on these sectors' production would potentially have large impacts on their upstream input suppliers. Symmetrically, sectors with large Ghosh supply-driven multipliers have strong forward linkages, which implies that production shocks on them would potentially have significant impacts on their downstream demanders.

Based on the Leontief and Ghosh supply-driven multipliers, backward and forward linkage indices can be constructed to reveal sectors' relative linkage strength. A sector's backward-linkage index is calculated by dividing its Leontief supply-driven multiplier by the average Leontief supply-driven multipliers for all the sectors. Thus, a backward-linkage index higher than one implies that the sector has strong backward linkage relative to other sectors in the economy. Forward linkage indices can be calculated similarly by using the Ghosh supply-driven multipliers. ${ }^{4}$

\footnotetext{
${ }^{3}$ One key feature of the supply-driven approach is to examine the impacts of changes in sectors' production, as compared to the demand-driven approach examining the impacts of changes in sector's final demands, or the primary-input-driven approach examining changes in sectors' primary inputs (Leung and Pooley, 2002; Papadas and Dahl, 1999). Since the Leontief model describes intersectoral relations from an input-purchasing perspective, Cai and Leung (2004) suggest using the Leontief supply-driven multiplier as a standard backward-linkage measure. On the other hand, as the Ghosh (1958) model captures inter-sectoral relations from an output-selling perspective, the Ghosh supply-driven multiplier is accordingly suggested as a standard forward-linkage measure.

${ }^{4}$ A brief discussion on the derivations of the supply-driven multipliers and the construction of linkage indices is provided in Appendix A, and more detailed discussion can be found in Cai and Leung (2004).
}

Table 2

Linkages of Hawaii's fisheries sectors (1997)

\begin{tabular}{llllll}
\hline Sectors & \multicolumn{2}{l}{ Backward linkage } & & \multicolumn{2}{c}{ Forward linkage } \\
\cline { 2 - 3 } \cline { 6 - 6 } \cline { 5 - 6 } & Measures & Indices & & Measures & Indices \\
\hline Tuna longline & 1.42 & 1.01 & & 1.33 & 1.03 \\
Swordfish longline & 1.44 & 1.02 & & 1.04 & 0.81 \\
Small commercial boats & 1.49 & 1.06 & & 1.33 & 1.03 \\
Charter boats & 1.52 & 1.07 & & 1.01 & 0.79 \\
Expense boats & 2.26 & 1.60 & & 1.33 & 1.03 \\
Recreation boats & 2.15 & 1.52 & & 1.00 & 0.78 \\
\hline
\end{tabular}

\subsection{Backward and forward linkages of Hawaii's fisheries sectors}

Based on a 26-sector input-output model for Hawaii's economy in 1997 (SMS, 2004) we have computed Hawaii fisheries sectors' backward- and forwardlinkage measures and indices; the results are presented in Table 2 and Fig. 1.

\subsubsection{Backward linkages}

The results show that all the six fisheries sectors have relatively strong (above-average) backward linkages, but their magnitudes differ.

The magnitude of tuna longline's backward linkage is 1.42 , implying that US\$ 1 of tuna longline production is backward linked to $42 \varnothing$ of the production of its direct and indirect upstream suppliers. Thirty-one cents of these $42 \propto$ belong to tuna longline's direct local suppliers such as food processing, manufacturing, services, etc., and the rest $11 \notin$ belong to its indirect local suppliers (e.g. the suppliers of its direct suppliers). The magnitude of swordfish longline's backward linkage is 1.44 , implying that US\$ 1 of swordfish longline production is backward linked to $44 \phi$ of the production of its upstream suppliers ( $33 \notin$ for its direct suppliers and $11 \phi$ for its indirect suppliers). ${ }^{5}$

Small commercial boats and charter boats have stronger backward linkages (1.49 and 1.52, respectively) than longline fisheries. This mainly reflects the fact that these two sectors rely relatively more on local suppliers. While the import content for tuna and

\footnotetext{
${ }^{5}$ Although $50 \%$ of swordfish longline's inputs are intermediate inputs (as opposed to $40 \%$ for tuna longline), swordfish longline's backward linkage (1.44) is only slightly higher than that of tuna longline (1.42). This is because swordfish longline imports a higher percentage of its inputs (17\%), much greater than tuna longline (9\%).
} 


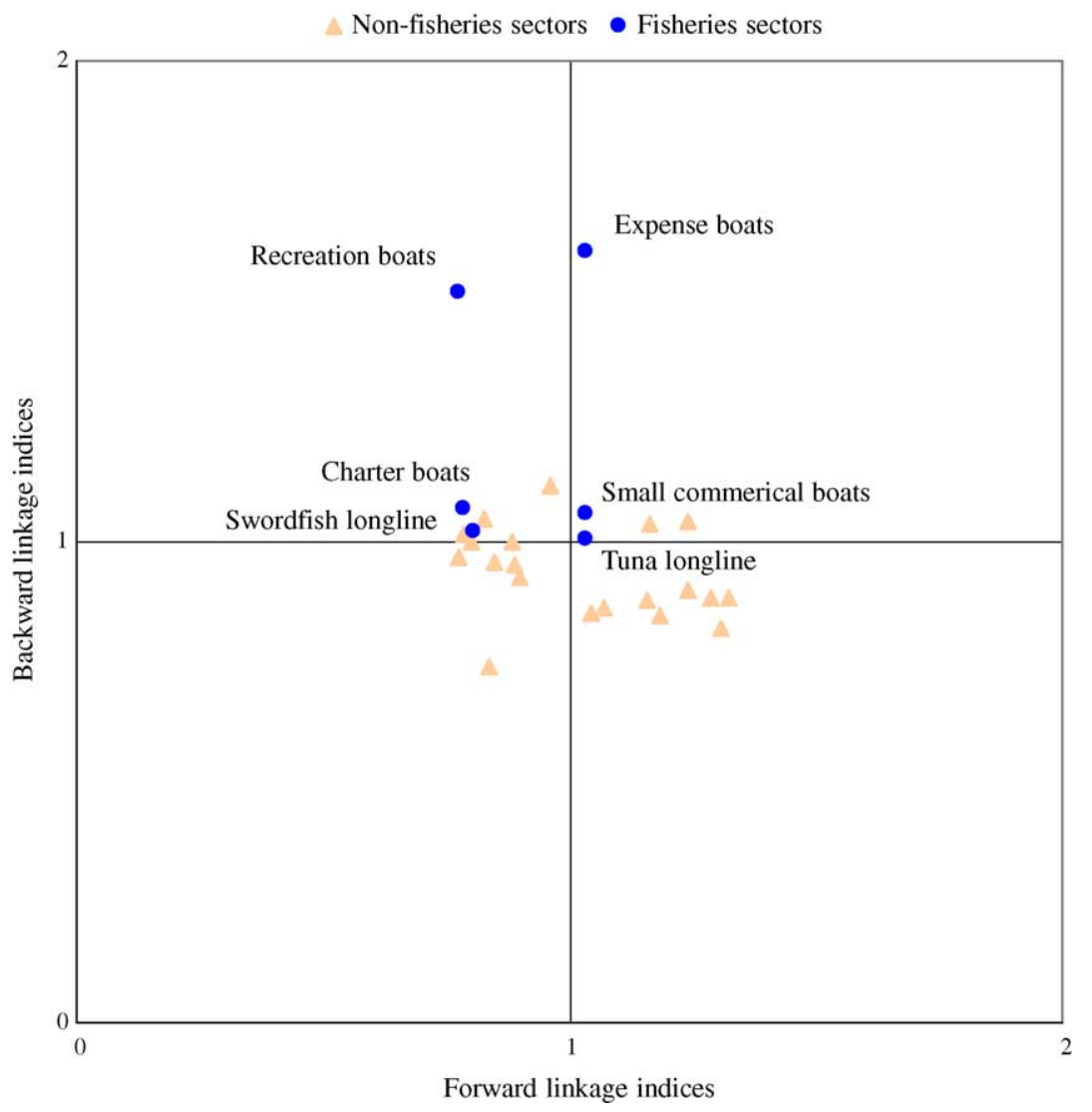

Fig. 1. Intersectoral linkages of Hawaii's fisheries sectors (1997).

swordfish longline is respectively $17 \%$ and $9 \%$ of their total inputs, that for small commercial boats and charter boats is $7 \%$ and $3 \%$, respectively.

Both expense boats and recreation boats have very strong backward linkages (2.26 and 2.15, respectively). This reflects the fact that the commercial value of fishes caught by expense/recreation boat owners is usually not sufficient to cover the expenses they spend in catching these fishes-after all, such fishing activities are for fun but not profit.

\subsubsection{Forward linkages}

Tuna longline, small commercial boats, and expense boats have forward linkage indices higher than one, implying relatively strong forward linkages, ${ }^{6}$ while

\footnotetext{
${ }^{6}$ Having also above-average backward linkages, these sectors are "key" sectors according to the linkage literature.
}

swordfish longline as well as recreation boats and charter boats have relatively weak forward linkages (Fig. 1).

Tuna longline, small commercial boats, and expense boats have similar forward linkages of 1.33 , implying that US\$ 1 of each sector's production is forward linked to $33 \phi$ of the production of its direct and indirect downstream demanders. In detail, for US\$ 1 of the production of tuna longline, $70 \notin$ are sold directly for final consumption, including $55 \notin$ for local consumption and $15 \phi$ for exports. The rest $30 \phi$ are bought by tuna longline's direct downstream demanders (e.g. hotels, eating and drinking, food processing, etc.) and hence constitute $30 \notin$ of their production. Through the intermediate sales of these direct downstream demanders, tuna longline can further contribute to $3 \phi$ of the production of its indirect downstream demanders.

As compared the other three commercial fisheries sectors just discussed, swordfish longline has relatively 
small forward linkage of 1.04, implying that US\$ 1 of the production of swordfish longline is only forward linked to $4 \phi$ of its downstream demanders. This reflects the fact that almost the entire swordfish production $(96.5 \%)$ are directly sold for final consumption, including $6.5 \%$ for local consumption and $90 \%$ for exports.

Both charter boats and recreation boats have fairly small forward linkages, 1.01 and 1.00, respectively. This should not be surprised because recreational services provided by these two sectors are mostly sold directly to final consumers (tourists or local residents).

\section{Economic impacts of Hawaii's longline fishing regulations}

Linkage analysis in the last section shows that all the six fisheries sectors in Hawaii have strong backward linkages, and most of Hawaii's commercial fisheries sectors (except swordfish longline) also have strong forward linkages. Therefore, economic impact assessment of fishing regulations should not be limited to the fisheries sectors being regulated, but should also consider the impacts on the rest of the economy through intersectoral linkages. Following this line, we will evaluate the economy-wide impacts of recent longline fishing regulations in Hawaii.

\subsection{Background}

Since longline fishing (longlining) ${ }^{7}$ was first introduced to Hawaii in 1917, Hawaii's longline fisheries have developed into a multimillion-dollar sector, harvesting mainly swordfish (Xiphius gladius) and tuna (Thunnus albacares and Thunnus obesus) for local, mainland U.S., and foreign markets. However, its continuing existence has been brought into question by recent regulatory changes due to environmental concerns.

As longlining poses a potential danger to accidentally catching protected species such as marine turtles and seabirds, a series of environmental lawsuits (starting from February 1999) sought substantial restrictions on longlining in Hawaii [e.g. Center

\footnotetext{
${ }^{7}$ Hereafter we refer to longline fishing as "longlining".
}

of Marine Conservation versus NMFS (D. Haw.) Civ. No. 99-00152 DAE (CMC versus NMFS)]. As a result, the Hawaii longline fishery for swordfish (swordfishing or swordfishery in short hereafter) was effectively banned in 2001, while tuna longlining was kept alive because of its relatively smaller by-catch impacts. Following the swordfishery shutdown, around one-third of swordfish-targeting vessels shifted their base from Hawaii to California; those who chose to stay in Hawaii converted their boats to tuna longlining.

Under a subsequent reconsideration of the issue, the swordfishing ban was replaced in 2004 by a restriction on the level of swordfishing (days) and an upper annual limit on turtle by-catch. That is, in any year, when predetermined limit for turtle interactions is reached, the entire Hawaii swordfishery will be halted for the rest of the year. This new regulation is expected to revive Hawaii's swordfishery sector; yet, the sector's longterm sustainability still depends on how well swordfishers can coordinate to internalize the externalities of their individual swordfishing operations to the entire sector. If effective coordination mechanisms cannot be established, uncertainties involved in swordfishing under the current regulatory framework may be prohibited. The situation could become more complicated as an upcoming swordfishing ban in California may lead to the return of the swordfish-targeting vessels that have left Hawaii after the 2000/2001 swordfishing ban. ${ }^{8}$

Designed for environmental benefits, the recent regulations placed on Hawaii's longline fisheries would nevertheless take a toll on the local economy. As sectors are interdependent, the impacts will go beyond longline fisheries and influence the entire economy through inter-sectoral economic linkages.

Leung and Pooley (2002) is one of the earlier attempts to estimate the impact of longline regulations on Hawaii's economy. Since the authors use the 1992 Hawaii input-output model that treats longline fisheries as a single sector without providing disaggregated information about swordfishing and tuna longlining, they are only able to consider potential economic impacts of shutting down the entire Hawaii's longline fisheries.

In the 1997 Hawaii fisheries input-output model recently developed by the National Marine Fisheries

\footnotetext{
${ }^{8}$ See the newspaper article "Longliners set to resume fishing: New rules may test fleet's ability to prosper" (by Will Hoover) in The Honolulu Advertiser, March 13, 2004.
} 
Service's Honolulu Laboratory (SMS, 2004), Hawaii's longline fisheries is disaggregated into tuna longline and swordfish longline as two sub-sectors. This disaggregation not only allows us to distinguish the economic impacts of swordfishing from those of the longline fishery as a whole, but also enables us to take into account interactions between swordfish longline and tuna longline. Besides, the 1997 model also provides more updated information about the structure of Hawaii's economy than the 1992 model; hence, estimations based on which tend to be more accurate.

Therefore, with the 1997 table we now can conduct a more refined assessment of the potential economic impacts of recent changes in Hawaii's longlining regulations.

\subsection{Methodology}

Based on the 1997 input-output model, we will estimate counterfactually how longlining regulations could have affected Hawaii's economy in 1997.

The estimation includes two steps. We first consider how longlining regulations could have directly affected longline sectors (i.e. self impacts); then we estimate how the self impacts could be spread to the rest of the economy through intersectoral input-output linkages (i.e. linkage impacts).

For the first step, we consider four scenarios. Motivated by the 2000/2001 swordfishing ban, the first scenario considers a situation where regulations cause a complete swordfishery shutdown, that is, swordfishing production becomes zero.

Following the 2000/2001 swordfishing ban, onethird of swordfish-targeting vessels shifted their base from Hawaii to California; those that stayed in Hawaii were converted to tuna longlining. To take this situation into account, in the second scenario we estimate the economic impacts of a swordfishing shutdown together with partial capacity shift from swordfishing to tuna longlining. Since tuna catch by Hawaii's longline fisheries is increased by about $15 \%$ on average following the 2000/2001 swordfishing ban, we assume that swordfishery closure would increase the production of tuna longlining by $15 \%$ through capacity shift. In sum, the second scenario is a situation where swordfishing production becomes zero, whereas the production of tuna longlining is increased by $15 \%$.
The third scenario is motivated by the recent 2004 longlining regulations that replace the 2000/2001 swordfishing ban with a restriction on swordfishing effort. Under the new regulations, Hawaii's swordfishtargeting efforts will be limited to 2120 "sets" per year, ${ }^{9}$ which amounts to about half of the swordfishing capacity prior to the swordfishing ban. Since a swordfishing ban is being implemented in California, those swordfish-targeting vessels that left Hawaii after the 2000/2001 swordfishing ban are expected to return home. Taking these elements into consideration, we consider a situation where swordfishing production is reduced by $50 \%$, yet tuna longlining production increases by $10 \%$. The $50 \%$ reduction in swordfishing production captures the self impact of the new longlining regulations that restrict swordfishing efforts by half. Suppose the other half of swordfishing capacity is converted to tuna longlining, we assume that it would increase tuna longlining production by $10 \%$. This assumption is based on the fact that with two-third of swordfish-targeting vessels being converted into tuna fishing after the 2000 swordfishing ban, the longlining tuna catch has increased by around $15 \%$.

Finally, the fourth scenario considers a complete shutdown of the entire longline fishery. This scenario provides information about the maximum potential economic costs of longlining restrictions.

With the self impacts of longlining regulations specified in the first step, the second step is to estimate their potential linkage impacts through both backward and forward linkages.

Similar to the method used in Leung and Pooley (2002), we use a Leontief supply-driven model to estimate how changes in longline fisheries will affect the rest of the economy through backward linkage. ${ }^{10}$ An implicit assumption behind such estimations is that

\footnotetext{
${ }^{9}$ One set equals one day's fishing per boat.

${ }^{10}$ Being a special case of the "mixed exogenous/endogenous variables" model discussed in Miller and Blair (1985, p. 325), the Leontief supply-driven model focuses on how an exogenous production shock on a sector (or sectors) would affect the production of the rest of the economy through backward linkage. While it is not an issue for the empirical study here that is based on the Hawaii 1997 fisheries input-output table, Steinback (2004) points out that applying the mixed exogenous/endogenous technique to a "readymade" input-output model (e.g. IMPLAN) can be computationally demanding, and suggests that setting the regional purchase coefficients (RPCs) for exogenously impacted sectors to zero can significantly reduce such computational complexity.
} 
longlining products can be perfectly substituted by imports; hence changes in longline sectors will not affect the businesses that use longlining products as inputs (e.g. restaurants). Thus, while the estimations based on the Leontief (supply-driven) model capture longline sectors' potential backward-linkage impacts on their upstream suppliers, they nevertheless overlook the sectors' potential forward-linkage impacts on their downstream demanders.

A Ghosh supply-driven model can be used to estimate longline sectors' potential forward-linkage impacts (Leung and Pooley, 2002). However, caution needs to be taken in interpreting the results. Since a stable output coefficient matrix (implicitly assumed by the Ghosh model) is hardly consistent with production reality, the interpretation of the Ghosh model as a quantity model has been viewed as "implausible" (Oosterhaven, 1988, 1989; Gruver, 1989). To interpret the Ghosh model as a price model is more justifiable theoretically (Dietzenbacher, 1997); yet, the underlying assumption of fixed productions makes the pricemodel interpretation less useful in impact evaluations under most situations including the present analysis.

In light of these problems, we take the estimations based on the Ghosh supply-driven model as informative yet indefinite measures of longline sectors' forward-linkage impacts. ${ }^{11}$ The measures are informative in that they indicate how much of which sectors' productions depend directly or indirectly on longlining products as inputs. On the other hand, the measures are indefinite in that they do not reveal exactly how changes in the availability of longlining products will affect the production of the affected sectors. These affected sectors could be kept intact by perfect import substitutions, or they could be completely lost because of no substitutions, or somewhere in between. Or, the impacts could be more profound. For example, the lack of affordable and fresh tuna sashimi could have negative impacts on the expansion of seafood restaurants in Hawaii. To take these complications into account needs more data than input-output tables can provide.

\footnotetext{
${ }^{11}$ We are aware of no standard input-output models that can definitely estimate forward linkage impacts. General equilibrium models are usually needed to estimate the "total" impact of output changes in a sector (or sectors) on the rest of the economy. Such models are also not problem-free. They are not only data demanding but also tend to require unrealistic assumptions that could lead to misleading results.
}

Thus, rather than ignoring the potential forwardlinkage impacts of longlining regulations, we choose to use the Ghosh supply-driven model to estimate how much production in which sectors could potentially be affected by longlining regulations through forward linkages.

The technical details on using the Leontief and Ghosh models to estimate the backward- and forwardlinkage impacts are provided in Appendix A. In the following we present the results of our estimations.

\subsection{Results}

The aggregate economic impacts of longline fishing regulations in the four scenarios are summarized in Table $3 .{ }^{12}$

\subsubsection{Scenario one: swordfishing shutdown}

A complete closure of Hawaii's swordfishery would mean that the sector's US\$ 23 million output $(0.085 \%$ of the total output in Hawaii's economy), ${ }^{13}$ US\$ 11 million value-added $(0.072 \%)$, US\$ 5.6 million income (0.065\%), 218 jobs $(0.232 \%)$, and US\$ 0.67 million state taxes $(0.022 \%$ ) would have been lost (in 1997 terms, Table 3).

In addition, through backward linkages, the closure would have caused losses in the rest of the economy, including US\$ 9.9 million output $(0.017 \%)$, US\$ 5.7 million value-added $(0.015 \%)$, US\$ 3.3 million income $(0.014 \%), 114$ jobs $(0.015 \%)$, and US\$ 0.67 million state taxes $(0.022 \%)$. The most backward-linkage affected sectors in the rest of the economy include wholesale trade, manufacturing, and services.

The potential forward-linkage impacts of the swordfishing shutdown are relatively small. Through forward linkages, the shutdown could have negatively affected US\$ 0.86 million output $(0.002 \%)$, US\$ 0.45 million value-added $(0.001 \%)$, US\$ 0.30 million income $(0.001 \%), 15$ jobs $(0.002 \%)$, and US\$ 0.05 million state taxes $(0.002 \%)$ in the rest of the economy. The most forward-linkage affected sectors include food services, food processing, and hotels.

\footnotetext{
12 Information about detailed impacts on individual sectors is available from the authors upon request.

${ }^{13}$ In the remainder of the paper, without specified otherwise, percentage numbers in parentheses are in terms of Hawaii's total.
} 
Table 3

Economic impacts of Hawaii longlining regulations

\begin{tabular}{|c|c|c|c|c|c|c|c|c|}
\hline Scenarios & Impacts & $\begin{array}{l}\text { Output } \\
\text { (US\$ million) }\end{array}$ & $\begin{array}{l}\text { Value-added } \\
\text { (US\$ million) }\end{array}$ & $\begin{array}{l}\text { Wage income } \\
\text { (US\$ million) }\end{array}$ & $\begin{array}{l}\text { Proprietor's income } \\
\text { (US\$ million) }\end{array}$ & $\begin{array}{l}\text { State taxes } \\
\text { (US\$ million) }\end{array}$ & $\begin{array}{l}\text { Wage } \\
\text { jobs }\end{array}$ & $\begin{array}{l}\text { Proprietor's } \\
\text { jobs }\end{array}$ \\
\hline \multirow[t]{3}{*}{ Swordfishing shutdown } & Self impact & -22.67 & -11.24 & -4.15 & -1.45 & -0.67 & -116 & -102 \\
\hline & Backward-linkage impact & -9.93 & -5.68 & -3.03 & -0.29 & -0.67 & -89 & -25 \\
\hline & Forward-linkage impact & -0.86 & -0.45 & -0.29 & -0.01 & -0.05 & -14 & 0 \\
\hline \multirow{3}{*}{$\begin{array}{l}\text { Swordfishing shutdown } \\
\text { with partial capacity } \\
\text { shift }\end{array}$} & Self impact & -18.56 & -8.77 & -3.05 & -1.08 & -0.53 & -83 & -74 \\
\hline & Backward-linkage impact & -8.20 & -4.69 & -2.49 & -0.24 & -0.56 & -72 & -20 \\
\hline & Forward-linkage impact & 0.49 & 0.24 & 0.16 & 0.01 & 0.02 & 9 & 0 \\
\hline \multirow{3}{*}{$\begin{array}{l}\text { Swordfishing restriction } \\
\text { with capacity shift }\end{array}$} & Self impact & -8.60 & -3.98 & -1.34 & -0.48 & -0.24 & -36 & -32 \\
\hline & Backward-linkage impact & -3.81 & -2.18 & -1.16 & -0.11 & -0.26 & -33 & -9 \\
\hline & Forward-linkage impact & 0.47 & 0.23 & 0.15 & 0.01 & 0.02 & 8 & 0 \\
\hline \multirow{3}{*}{$\begin{array}{l}\text { Longline fisheries } \\
\text { shutdown }\end{array}$} & Self impact & -50.04 & -27.71 & -11.45 & -3.94 & -1.64 & -331 & -293 \\
\hline & Backward-linkage impact & -21.44 & -12.30 & -6.64 & -0.67 & -1.41 & -200 & -58 \\
\hline & Forward-linkage impact & -9.85 & -5.05 & -3.25 & -0.15 & -0.54 & -167 & -6 \\
\hline
\end{tabular}




\subsubsection{Scenario two: swordfishing shutdown with partial capacity shift}

Accompanied by a $15 \%$ increase in tuna longlining production due to partial capacity shift from swordfishery, the economic costs incurred by both self and linkage impacts of swordfishery closure will be smaller than the first scenario (Table 3).

Indeed, as tuna longline has a much stronger forward linkage than swordfish longline, the forward-linkage impacts of swordfishing shutdown in this scenario are positive. Put plainly, as most of Hawaii's swordfish is for exports, swordfishery closure may not have much impact on local restaurants, retail grocery, or other businesses. If any, these businesses might be able to benefit from more tuna supply due to the capacity shift from swordfishery to tuna longlining. Detailed impacts on individual sectors show that the capacity shift could almost neutralize the negative forward-linkage impact of swordfishing shutdown on hotels, while the outputs of the eating and drinking sector and the food processing sector could actually be increased by the swordfishing shutdown.

\subsubsection{Scenario three: swordfishing restriction with capacity shift}

Suppose swordfishing restrictions reduced swordfishery production by half, yet increased the tuna longlining production by $10 \%$ in 1997 ; then its impact on Hawaii's economy would have been such as shown by the second last row in Table 3 .

Not surprisingly, the self-impact economic losses in the situation are smaller than the case of a complete swordfishing shutdown; so are the backward-linkage impacts. The forward-linkage impacts in this situation are similar to those in the case of swordfishing shutdown with capacity shift. This is because, while preserving half of swordfishing output reduces the negative forward-linkage impacts of longlining regulations, it also reduces the positive forward-linkage impacts due to the capacity shift from swordfishing to tuna longlining.

\subsubsection{Scenario four: closure of the entire longline fisheries}

Had the longline fisheries been completely shut down in 1997, Hawaii's economy would have been affected in such a way as shown by the last row in Table 3. The self-impact losses would be longline fisheries' direct economic contributions (output, value-added, jobs, etc.). Since tuna longline has a relatively strong forward linkage, the closure of the entire longline fisheries will potentially have both significant backward- and forward-linkage impacts. The most affected sectors through backward linkages are wholesale trade, manufacturing, and services; and the most affected sectors through forward linkages are eating and drinking, hotels, and food processing.

\section{Conclusions}

Linkage analysis in this paper finds that Hawaii's longline and other fisheries sectors have strong economic linkages to the rest of the economy, and hence the economic impacts of longlining regulations would go beyond the fisheries sectors being restricted. Therefore, it is imperative for policymakers to take such linkage impacts into account in decision making on longlining (or other fishing) regulations.

Based on the Hawaii 1997 fisheries input-output model, we have estimated the economic impacts of longlining regulations in four counterfactual scenarios. If the structure of Hawaii's economy has not changed much since 1997 (the updated model base year), these estimates (including the magnitudes and percentages) can provide approximate measures of the economic impacts of the 2000/2001 swordfishing ban, the current swordfishing restrictions which partially re-open swordfishery, and the effect of a complete shutdown of the entire longline fishery (as a strictly hypothetical case).

Since our focus here is on linkage impacts, we have only considered some simple interactions (i.e. the assumed capacity shift) among fisheries sectors under longlining regulations, which could actually be more complicated (Pradhan and Leung, 2004; Pradhan et al., 2003; Sharma et al., 2003). For example, longlining regulations would not only affect longline fishers' choices of fishing techniques and targeting species but also tend to influence their entry, stay, or exit decisions. Therefore, in order to provide more accurate estimation of the long-term impacts of longlining regulations, future research should consider linking behavioral models and input-output models to estimate the impacts of longlining regulations on the sizes of longline fisheries sectors and the corresponding linkage impacts. Another 
complication is interactions between fisheries sectors that tend to compete for limited fisheries resources. For example, tuna longlining expansion due to swordfishing ban or restriction could reduce the production or value of production of small commercial boats through competitive pressures; and similar negative impacts could also happen to charter boats. To provide more accurate impact evaluations, future research should also take these complications into account.

\section{Acknowledgements}

This study was funded by Cooperative Agreement NA17RJ1230 between the Joint Institute for Marine and Atmospheric Research (JIMAR) and the National Oceanic and Atmospheric Administration (NOAA). The views expressed herein are those of the authors and do not necessarily reflect the views of NOAA or any of their subdivisions. The authors are also indebted to the two anonymous journal reviewers for their constructive comments and suggestions. The usual caveats apply.

\section{Appendix A}

\section{A.1. Leontief supply-driven multiplier as a backward-linkage measure}

Partition the Leontief input-output model $\boldsymbol{x}=\mathbf{A} \boldsymbol{x}+\boldsymbol{f}$ ( $\boldsymbol{x}$ and $\boldsymbol{f}$ are the vectors of output and final demand, respectively, and $\mathbf{A}$ is the direct input coefficient matrix) into

$$
\left(\begin{array}{c}
x_{i} \\
\boldsymbol{x}_{j}
\end{array}\right)=\left(\begin{array}{cc}
\mathbf{A}_{i i} & \mathbf{A}_{i j} \\
\mathbf{A}_{j i} & \mathbf{A}_{j j}
\end{array}\right)\left(\begin{array}{c}
x_{i} \\
\boldsymbol{x}_{j}
\end{array}\right)+\left(\begin{array}{c}
f_{i} \\
\boldsymbol{f}_{j}
\end{array}\right),
$$

where $i$ denotes sector $i$, and $j$ represents the rest of the economy. According to the partitioned model, the backward-linkage impacts of sector $i$ 's one-unit output change (i.e. $\Delta x_{i}=1$ ) on other sectors can be calculated by $\Delta \boldsymbol{x}_{j}=\left(\boldsymbol{I}-\mathbf{A}_{j j}\right)^{-1} \mathbf{A}_{j i}$. Then, sector $i$ 's Leontief supply-driven multiplier (denoted as $\mathrm{LSD}_{i}$ ) is given by

$$
\operatorname{LSD}_{i}=1+\boldsymbol{e}^{\prime}\left(\boldsymbol{I}-\mathbf{A}_{j j}\right)^{-1} \mathbf{A}_{j i},
$$

where $\boldsymbol{e}$ is the summation vector. $\mathrm{LSD}_{i}$ provides a standard backward-linkage measure for sector $i$. For the purpose of inter-sectoral comparison, sector $i$ 's backward-linkage index can be calculated by

$\frac{\mathrm{LSD}_{i}}{\mathrm{LSD}_{i}+\sum_{j} \mathrm{LSD}_{j}}$.

\section{A.2. Ghosh supply-driven multiplier as a forward-linkage measure}

Partition the Ghosh input-output model $\boldsymbol{x}^{\prime}=\boldsymbol{x}^{\prime} \mathbf{B}+$ $\boldsymbol{w}^{\prime}$ ( $\boldsymbol{x}$ and $\boldsymbol{w}$ are the vectors of output and primary input, respectively, and $\mathbf{B}$ is the direct output coefficient matrix) into

$$
\left(\begin{array}{ll}
x_{i}^{\prime} & \boldsymbol{x}_{j}^{\prime}
\end{array}\right)=\left(\begin{array}{ll}
x_{i}^{\prime} & \boldsymbol{x}_{j}^{\prime}
\end{array}\right)\left(\begin{array}{ll}
\mathbf{B}_{i i} & \mathbf{B}_{i j} \\
\mathbf{B}_{j i} & \mathbf{B}_{j j}
\end{array}\right)+\left(\begin{array}{ll}
\boldsymbol{w}_{i}^{\prime} & \boldsymbol{w}_{j}^{\prime}
\end{array}\right) ;
$$

according to which the forward-linkage impacts of sector $i$ 's one-unit output change (i.e. $\Delta x_{i}=1$ ) on other sectors can be calculated by $\Delta \boldsymbol{x}_{j}^{\prime}=\mathbf{B}_{i j}\left(\boldsymbol{I}-\mathbf{B}_{j j}\right)^{-1}$. Then, sector $i$ 's Ghosh supply-driven multiplier (denoted as $\mathrm{GSD}_{i}$ ) is given by

$G S D_{i}=1+\mathbf{B}_{i j}\left(\boldsymbol{I}-\mathbf{B}_{j j}\right)^{-1} \boldsymbol{e}$,

which provides a standard forward-linkage measure for sector $i$. For the purpose of inter-sectoral comparison, sector $i$ 's forward linkage index can be calculated by

$$
\frac{\mathrm{GSD}_{i}}{\mathrm{GSD}_{i}+\sum_{j} \mathrm{GSD}_{j}} .
$$

\section{A.3. Backward-and forward-linkage impacts of longlining regulations}

Partition the Leontief input-output model into

$$
\left(\begin{array}{c}
\boldsymbol{x}_{i} \\
\boldsymbol{x}_{j}
\end{array}\right)=\left(\begin{array}{ll}
\mathbf{A}_{i i} & \mathbf{A}_{i j} \\
\mathbf{A}_{j i} & \mathbf{A}_{j j}
\end{array}\right)\left(\begin{array}{c}
\boldsymbol{x}_{i} \\
\boldsymbol{x}_{j}
\end{array}\right)+\left(\begin{array}{c}
\boldsymbol{f}_{i} \\
\boldsymbol{f}_{j}
\end{array}\right),
$$

where $\boldsymbol{x}_{i}$ is a $2 \times 1$ vector with the two elements being the outputs of swordfishing and tuna longlining. $x_{j}$ is a $24 \times 1$ vector with the elements being other sectors' outputs. Based on this partitioned modeled, the backward-linkage impacts of changes in the longlining sectors on other sectors can be calculated by the 
following formula:

$\Delta \boldsymbol{x}_{j}=\left(\boldsymbol{I}-\mathbf{A}_{j j}\right)^{-1} \mathbf{A}_{j i} \Delta \boldsymbol{x}_{i}$,

where $\Delta \boldsymbol{x}_{i}^{\prime}=(-22.67,0)$ for the case of swordfishing shutdown; $\Delta \boldsymbol{x}_{i}^{\prime}=(-22.67,4.11)$ for the case of swordfishing shutdown with capacity shift; $\Delta \boldsymbol{x}_{i}^{\prime}=$ $(-11.34,2.74)$ for the case of swordfishing restriction; and $\Delta \boldsymbol{x}_{i}^{\prime}=(-22.67,-27.37)$ for the case of the shutdown of the entire longline fishery.

Similarly, based on a partitioned Ghosh model, the forward-linkage impacts of changes in the longlining sectors on other sectors can be calculated by the following formula:

$\Delta \boldsymbol{x}_{j}^{\prime}=\Delta \boldsymbol{x}_{i}^{\prime} \boldsymbol{B}_{i j}\left(\boldsymbol{I}-\boldsymbol{B}_{j j}\right)^{-1}$

\section{References}

Cai, J., Leung, P.S., 2004. Linkage measures: a revisit and a suggested alternative. Econ. Syst. Res. 16, 65-85.

Chenery, H.B., Watanabe, T., 1958. International comparison of the structure of production. Econometrica 26, 487-521.

Dietzenbacher, E., 1997. In vindication of the Ghosh model: a reinterpretation as a price model. J. Reg. Sci. 37, 629-651.

Ghosh, A., 1958. Input-output approach to an allocation system. Economica 25, 58-64.

Gruver, G.W., 1989. On the plausibility of supply-driven input-output model: a theoretical basis for input-coefficient change. J. Reg. Sci. 29, 441-450.
Hirschman, A.O., 1958. The Strategy of Economic Development. Yale University Press, New Haven.

Leung, P.S., Pooley, S., 2002. Regional economic impacts of reductions in fisheries production: a supply-driven approach. Mar. Resource Econ. 16, 251-262.

Miller, R.E., Blair, P.D., 1985. Input-Output Analysis: Foundations and Extensions. Prentice-Hall, London.

Oosterhaven, J., 1988. On the plausibility of the supply-driven input-output model. J. Reg. Sci. 28, 203-217.

Oosterhaven, J., 1989. The supply-driven input-output model: a new interpretation but still implausible. J. Reg. Sci. 29, 459465.

Papadas, C.T., Dahl, D.C., 1999. Supply-driven input-output multipliers. J. Agric. Econ. 50, 269-285.

Pradhan, N.C., Leung, P.S., 2004. Modeling entry, stay, and exit decisions of the longline fishers in Hawaii. Mar. Policy 28, 311324.

Pradhan, N.C., Sharma, K.R., Leung, P.S., 2003. Analyzing technical and economic interrelationships in Hawaii's longline fishery. Mar. Resource Econ. 18, 167-193.

Sharma, K.R., Pradhan, N.C., Leung, P.S., 2003. Technological and economic interrelationships in Hawaii's troll and handline fisheries. North Am. J. Fisheries Manag. 23, 869-882.

SMS Research Inc., 2004. 1997 Fishery Input-Output Model \& Methodology. Honolulu, Hawaii. 28 pp.

Steinback, S.R., 2004. Using ready-made regional input-output models to estimate backward-linkage effects of exogenous output shocks. Rev. Reg. Stud. 34, 57-71. 